\title{
CASCADED H-BRIDGE MULTILEVEL INVERTER FOR INDUCTION MOTOR DRIVES
}

\author{
A.Venkadesan ${ }^{1}$, Priyatosh Panda ${ }^{2}$, Priti Agrawal ${ }^{3}$, Varun Puli ${ }^{4}$ \\ ${ }^{I}$ Asst Professor, Electrical and Electronics Engineering, SRM University, T.N, India \\ ${ }^{2}$ Student, Electrical and Electronics Engineering, SRM University, T.N, India \\ ${ }^{3}$ Student, Electrical and Electronics Engineering, SRM University, T.N, India \\ ${ }^{4} P G$ student, Electrical and Electronics Engineering, SRM University, T.N, India
}

\begin{abstract}
This paper proposes a cascaded H-Bridge Multilevel inverter for induction motor drives. Multi-level Inverter (MLI) has several advantages over conventional inverter such as lower total harmonic distortion (THD), low switching loss, good power quality, high output voltage. The main feature of multilevel inverter is that it uses many small dc sources to supply various output levels. The Hbridge cascaded MLI is chosen in this paper because it requires least number of components for same voltage level. The $H$ bridge cascaded MLI with five levels is designed. The simple multi carrier SPWM techniques namely phase disposition (PD) is used to generate pulses for the MLI. The H-bridge cascaded MLI with five levels using PD modulation technique is designed for induction motor drives. The performance of designed MLI fed induction motor drives is investigated extensively for various operating conditions through MATLAB simulation. The performance of MLI is also compared with conventional three phase inverter in terms of THD. The promising and interesting results obtained are comprehensively presented.
\end{abstract}

Keywords: Cascaded H-bridge Inverter, Multilevel Inverters, Pulse Width Modulation (PWM), induction motor drives.

\section{INTRODUCTION}

Over many years, Induction motor drives have been popularly used for variable speed control applications in industries. This is because the induction motor is simple in construction and requires less maintenance. In recent times, multilevel inverters (MLI) are gaining popularity and widely used for induction motor drive applications [1-3]. It is especially used for medium to high voltage and high current drive applications. There are many advantages of multilevel inverters as compared to conventional inverters. Main advantages are low total harmonics distortion (THD), low switching losses, good power quality and reduced electromagnetic interference (EMI). Main feature of multilevel inverter is that it reduces voltage stress on each component [48]. The topologies of multilevel inverters are classified into three types. They are flying capacitor, diode clamped and $\mathrm{H}-$ bridge cascaded multilevel inverters.

Cascaded H-bridge (CHB) multilevel inverter is one of the most popular inverter topology used in high-power mediumvoltage (MV) drives. It is composed of a multiple units of single-phase H-bridge power cells. In practice, the number of power cells in a CHB inverter is mainly determined by its operating voltage and manufacturing cost. Cascaded $\mathrm{H}$-bridge multilevel inverter requires the least number of components for the same voltage level as compared to all three types of inverter [9-11]. The growth of multilevel inverter caused development of various modulation schemes. There are many types of multi carrier PWM techniques namely phase disposition (PD), alternate phase opposition disposition (APOD), phase opposition disposition (POD). Phase disposition method provides the best harmonic profile of all three modulation schemes [12-15]. In this method all the carrier waves are in same phase and have same amplitude and frequency.

In this paper, $\mathrm{H}$ Bridge cascaded MLI with five levels is designed for induction motor drives. A simple PD sinusoidal PWM technique is used to generate switching pulses for the MLI. The performance of designed MLI fed induction motor drive is investigated extensively for various operating conditions. The performance of MLI is compared with conventional inverter in terms of THD under same operating conditions.

The paper is organized as follows. Section 2 details the cascaded MLI fed induction motor drives. The performance investigation of the designed MLI fed induction motor drive is carried out; simulation results are presented and discussed in section 3. The performance of MLI and conventional inverter is compared and results are presented in section 4 . Section 5 concludes the paper. 


\section{CASCADED MULTILEVEL INVERTER FED INDUCTION MOTOR DRIVES}

The MLI fed induction motor drives is shown as a block diagram in Fig.1. The cascaded H bridge MLI circuit consists of individual H-bridge cell which is fed by individual dc supply. Each H-bridge cell contains four switches. In this topology, IGBT is used as switch because of its low switching losses. Each H-bridge generates three different output voltages, $+\mathrm{Vdc}, 0$ and $-\mathrm{Vdc}$ using various combinations of switching with the four switches. For five levels, each leg consists of two H-bridge cells as shown in Fig. 2.

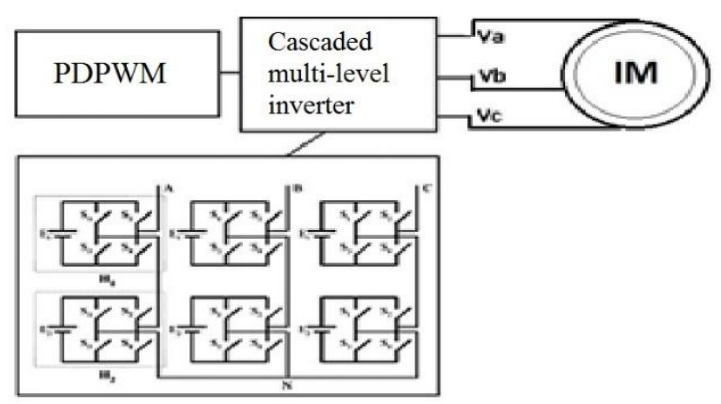

Fig-1 Block diagram of proposed system

The number of output phase voltage levels in a cascaded inverter is given in equation (1),

$$
m=2 H+1
$$

Where $\mathrm{H}$ is the number of $\mathrm{H}$-bridge and $\mathrm{m}$ is the inverter level. The constant switching frequency pulse-width modulation technique is most popular and very simple switching schemes. For $m$-level inverter $(m-1)$ carriers with the same frequency $f_{c}$ and the same amplitude $A_{c}$ are disposed such that the bands occupied are contiguous. The reference waveform has peakto-peak amplitude $A_{m}$, the frequency $f_{m}$. The reference is continuously compared with each of the carrier signals. If the reference is greater than $\mathrm{s}$ carrier signal, then the active device corresponding to that carrier is switched off. The frequency modulation index and amplitude modulation index is given in equation (2) and (3).

$$
\begin{aligned}
& M_{a}=\frac{A_{m}}{(m-1) A_{c}} \\
& M_{f}=\frac{f_{c}}{f_{m}}
\end{aligned}
$$

Phase disposition pulse width modulation (PDPWM) scheme provides the best harmonic profile among all the multi-carrier pulse width modulation technique and it is simple [12]. In PDPWM technique all the carrier waves are in phase. All the carrier waves have same frequency and amplitude. This scheme is shown in Fig 3.

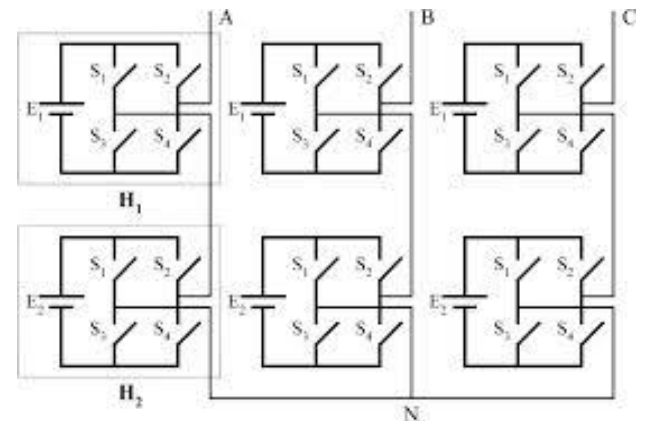

Fig- 2: Five level cascaded H-bridge multilevel inverter topology

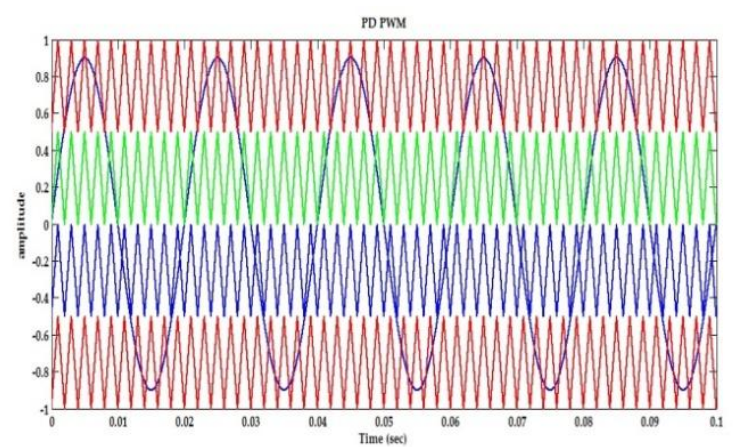

Fig-3 Phase disposition pulse width modulation (PDPWM) technique

\section{PERFORMANCE OF FIVE LEVEL H BRIDGE CASCADED MULTILEVEL INVERTER FED INDUCTION MOTOR DRIVES}

The performance of five level-MLI fed induction motor drives is investigated for various operating conditions. The PD SPWM is used to generate switching pulses for the MLI. The switching frequency is chosen as $5 \mathrm{KHz}$. The dc voltage of each cell is 188 Volts. The performance of designed MLI fed induction motor drives is tested extensively for various operating conditions. The sample results for major operating conditions are presented. The operating conditions are explained in terms of operating frequency and load instead of speed and load for convenience. The major operating conditions are,

1. Frequency of $50 \mathrm{~Hz}$ with a step change in load torque from $0 \%$ to $100 \%$.

2. Frequency of $50 \mathrm{~Hz}$ with a step change in load torque from $100 \%$ to $50 \%$.

3. Change in Frequency from $50 \mathrm{~Hz}$ to the low frequency of $12.5 \mathrm{~Hz}$ under no load condition.

4. Change in Frequency from $50 \mathrm{~Hz}$ to the low frequency of $12.5 \mathrm{~Hz}$ under $100 \%$ load condition. 


\subsection{Operating Condition 1}

In this test step change of load torque is applied from $0 \mathrm{Nm}$ to $7.5 \mathrm{Nm}$. Modulation index is 0.9 and supply frequency is given as $50 \mathrm{~Hz}$. Waveform of load torque, rotor speed and three phase stator current is shown in Fig.4,5 and 6 respectively.

\subsection{Operating Condition 2}

In this test step change of load torque is applied from $7.5 \mathrm{Nm}$ to $7.5 / 2 \mathrm{Nm}$. modulation index is 0.9 and supply frequency is given as $50 \mathrm{~Hz}$. Waveform of load torque, rotor speed and three phase stator current is shown in Fig.7,8 and 9 respectively.

\subsection{Operating Condition 3}

In this test load torque is maintain constant at $0 \mathrm{Nm}$. Supply frequency is changed from $50 \mathrm{~Hz}$ to $50 / 4 \mathrm{~Hz}$ and modulation index from 0.9 to $0.9 / 4$, to maintain V/f ratio as constant so that magnetising flux does not changes, the change is applied in ramp. Waveforms of load torque and rotor speed are shown in Fig.10 and 11 respectively.

\subsection{Operating Condition 4}

In this test load torque is maintain constant at $7.5 \mathrm{Nm}$. Supply frequency is changed from $50 \mathrm{~Hz}$ to $50 / 4 \mathrm{~Hz}$ and modulation index from 0.9 to $0.9 / 4$, the change is applied in ramp. Waveforms of load torque and rotor speed are shown in Fig.12 and 13 respectively.

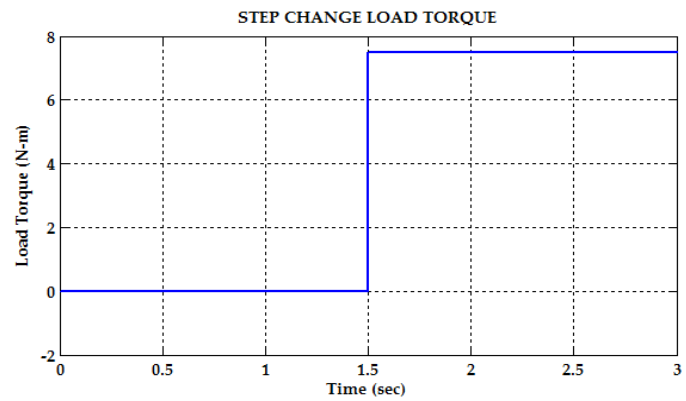

Fig-4 Load torque for operating condition 1

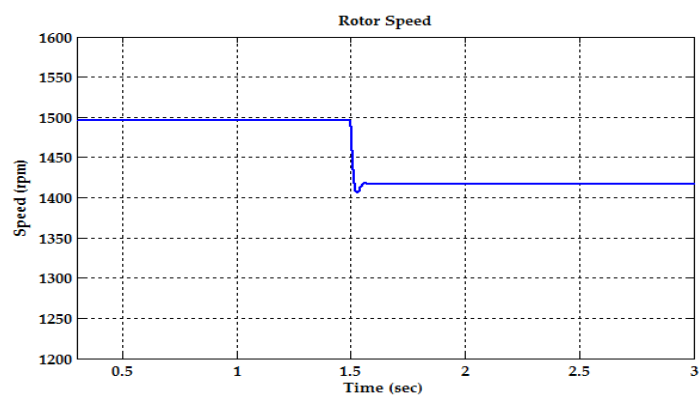

Fig-5 Rotor speed for operating condition 1

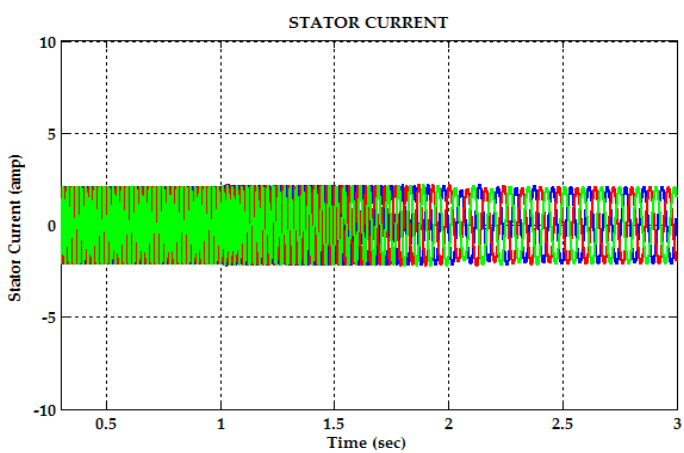

Fig-6 Three phase Stator Current for operating condition 1

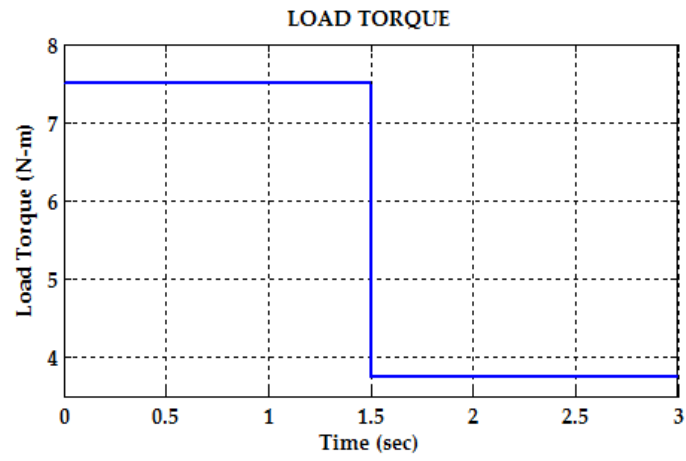

Fig-7 Load torque for operating condition 2

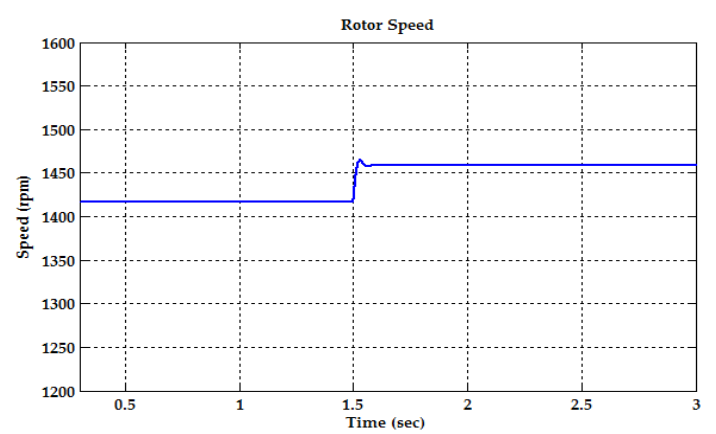

Fig-8 Rotor speed for operating condition 2

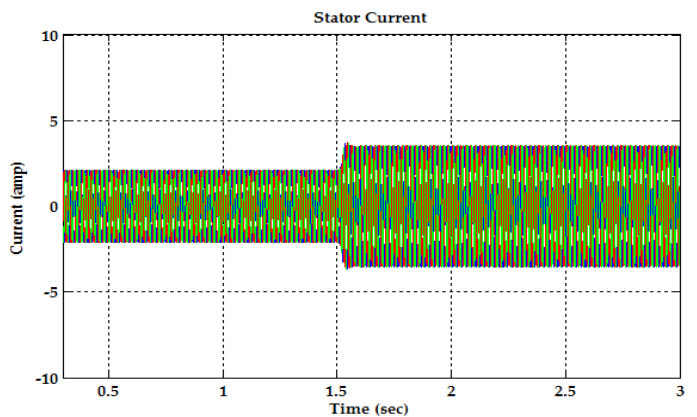

Fig-9 Three phase Stator Current for operating condition 2 


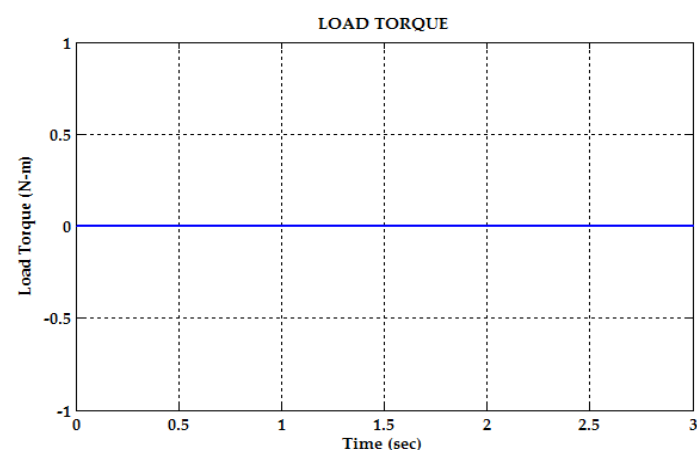

Fig-10 Load torque for operating condition 3

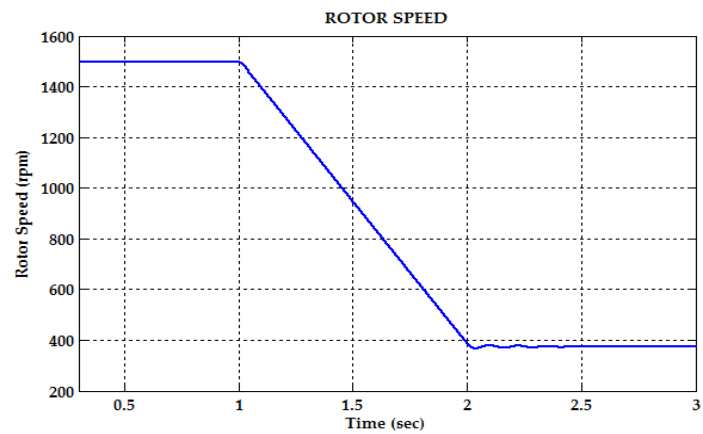

Fig-11 Rotor speed for operating condition 3

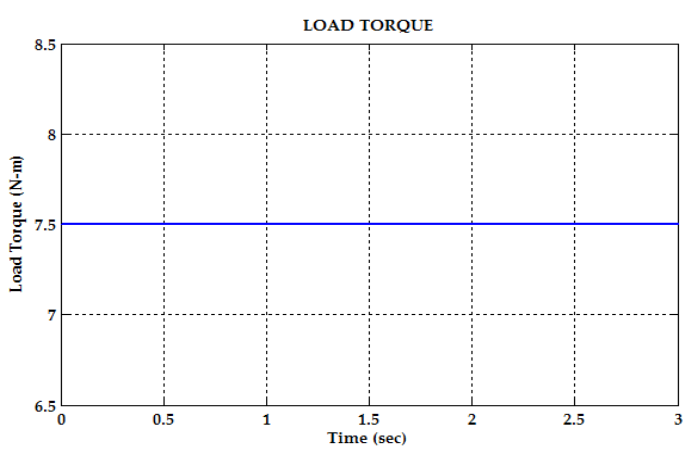

Fig-12 Load torque for operating condition 4

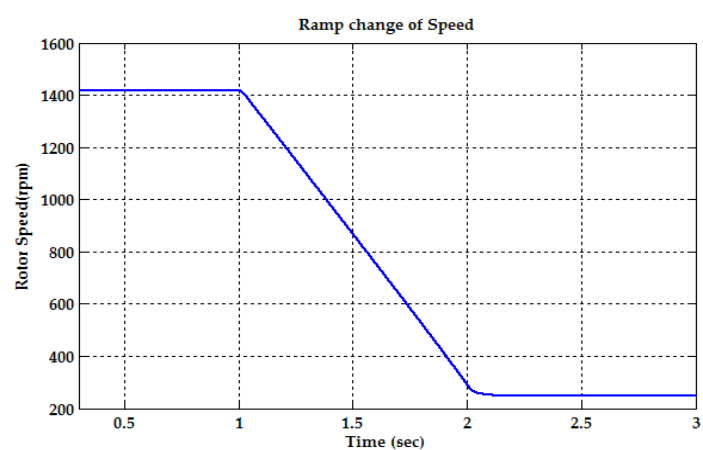

Fig-13 Rotor speed for operating condition 4
Table-1 Performance of MLI Fed Induction Motor Drive for Various Modulation Index/frequencies under 0\% Load Torque

\begin{tabular}{||l||l||l||}
\hline Modulation index & Frequency $(\mathrm{Hz})$ & Speed(RPM) \\
\hline \hline 0.9 & 50 & 1496 \\
\hline \hline 0.8 & 44.44 & 1330 \\
\hline \hline 0.7 & 38.88 & 1164 \\
\hline \hline 0.6 & 33.33 & 997.3 \\
\hline \hline 0.5 & 27.77 & 831.3 \\
\hline \hline 0.4 & 22.22 & 654.6 \\
\hline 0.3 & 16.66 & 498.5 \\
\hline \hline 0.2 & 11.11 & 332.7 \\
\hline \hline 0.1 & 5.55 & 166 \\
\hline
\end{tabular}

Table- 2 Performance of MLI Fed Induction Motor Drive for Various Modulation Index/frequencies under 50\% Load Torque

\begin{tabular}{|l|l|l||}
\hline Modulation index & Frequency $(\mathrm{Hz})$ & Speed(RPM) \\
\hline \hline 0.9 & 50 & 1415 \\
\hline \hline 0.8 & 44.44 & 1292 \\
\hline 0.7 & 38.88 & 1126 \\
\hline \hline 0.6 & 33.33 & 959.2 \\
\hline 0.5 & 27.77 & 792.4 \\
\hline \hline 0.4 & 22.22 & 624.8 \\
\hline
\end{tabular}

Table- 3 Performance of MLI Fed Induction Motor Drive for Various Modulation Index/frequencies under100\% Load Torque

\begin{tabular}{||l||l||l||}
\hline $\begin{array}{l}\text { Modulation } \\
\text { index }\end{array}$ & $\begin{array}{l}\text { Frequency } \\
(\mathrm{Hz})\end{array}$ & Speed(RPM) \\
\hline \hline 0.9 & 50 & 1415 \\
\hline \hline 0.8 & 44.44 & 1249 \\
\hline \hline 0.7 & 38.88 & 1082 \\
\hline \hline 0.6 & 33.33 & 913.2 \\
\hline \hline 0.5 & 27.77 & 744 \\
\hline \hline 0.4 & 22.22 & 572.6 \\
\hline
\end{tabular}

The performance of MLI fed induction motor drive is investigated for various operating conditions. The rotor speed of MLI fed IM drive for various modulation indexes/frequencies for $0 \%, 50 \%$ and $100 \%$ load torque are presented in Table I, Table II and Table III respectively. From the results obtained, it is observed that the MLI fed induction motor drive performs well for all the operating conditions. 


\section{PERFORMANCE COMPARISON OF MLI}

\section{WITH CONVENTIONAL INVERTER}

The performance of the proposed five level-cascaded multilevel Inverter is compared with conventional popular three phase two level inverter in terms of total harmonic distortion of both voltage and current. For performance comparison, MLI fed IM drive and conventional inverter fed induction motor drive is operated with the frequency of $50 \mathrm{~Hz}$ under $100 \%$ load torque. For the both inverter, the switching frequency is chosen as $5 \mathrm{KHz}$. The results obtained is consolidated and presented in Table IV. From the results obtained, it is obvious that the THD of voltage and current for MLI fed IM drives is much lesser as compared to conventional inverter fed IM drive.

Table-4 Comparison of conventional and MLI fed induction motor.

\begin{tabular}{||l||l|l|l||l||}
\hline $\begin{array}{l}\text { Switching } \\
\text { frequency } \\
\mathrm{KHz}\end{array}$ & $\begin{array}{l}\text { Conventional } \\
\text { Inverter fed } \\
\text { induction motor }\end{array}$ & \multicolumn{2}{|l|}{$\begin{array}{l}\text { Five level MLI fed } \\
\text { induction motor }\end{array}$} \\
\hline \multirow{3}{*}{$5 \mathrm{KHz}$} & $\begin{array}{l}\text { Current } \\
\text { THD } \\
\%\end{array}$ & $\begin{array}{l}\text { Voltage } \\
\text { THD \% }\end{array}$ & $\begin{array}{l}\text { Current } \\
\text { THD } \\
\%\end{array}$ & $\begin{array}{l}\text { Voltage } \\
\text { THD \% }\end{array}$ \\
& 2.73 & 85.37 & 0.52 & 17.39 \\
\hline
\end{tabular}

The line voltage $\mathrm{V}_{\mathrm{ab}}$ of the conventional three phase two level inverter and MLI are shown in Fig.14 (a) and (b) respectively. The line voltage $\mathrm{V}_{\mathrm{bc}}$ of the conventional three phase two level inverter and MLI are shown in Fig.15 (a) and (b) respectively. The line voltage $\mathrm{V}_{\mathrm{ac}}$ of the conventional three phase two level inverter and MLI are shown in Fig.16 (a) and (b) respectively. The phase currents of the conventional three phase two level inverter and MLI are shown in Fig.17 (a) and (b) respectively.

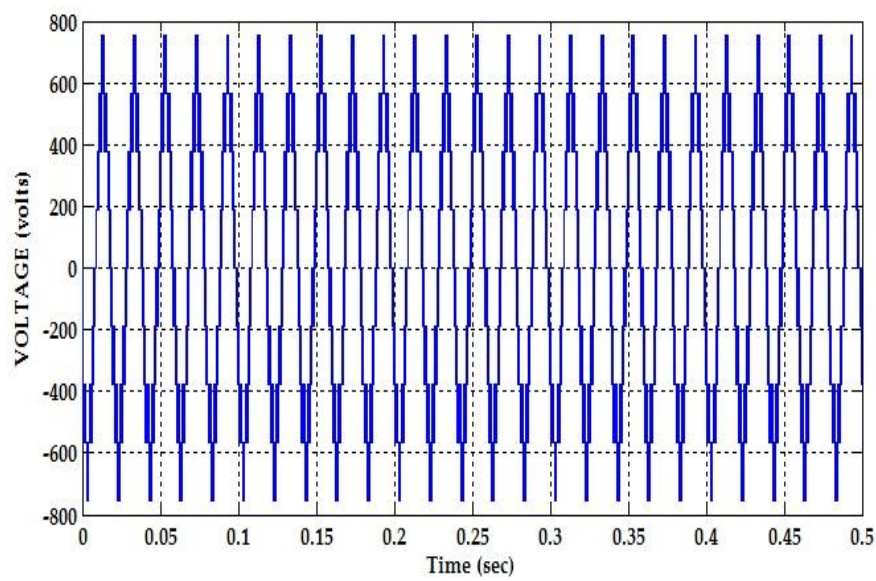

(a)

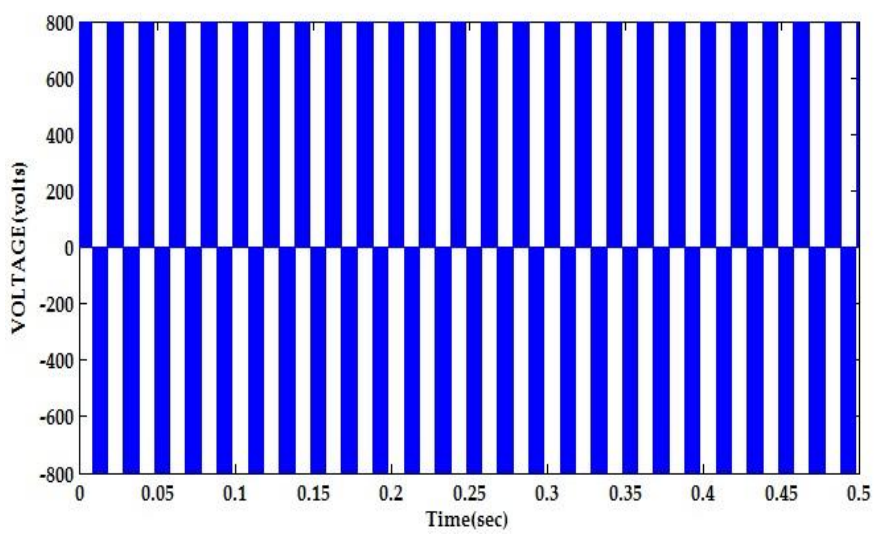

(b)

Fig-14 Line voltage $\mathrm{V}_{\mathrm{ab}}$ of induction motor load for (a) multilevel inverter (b)conventional inverter.

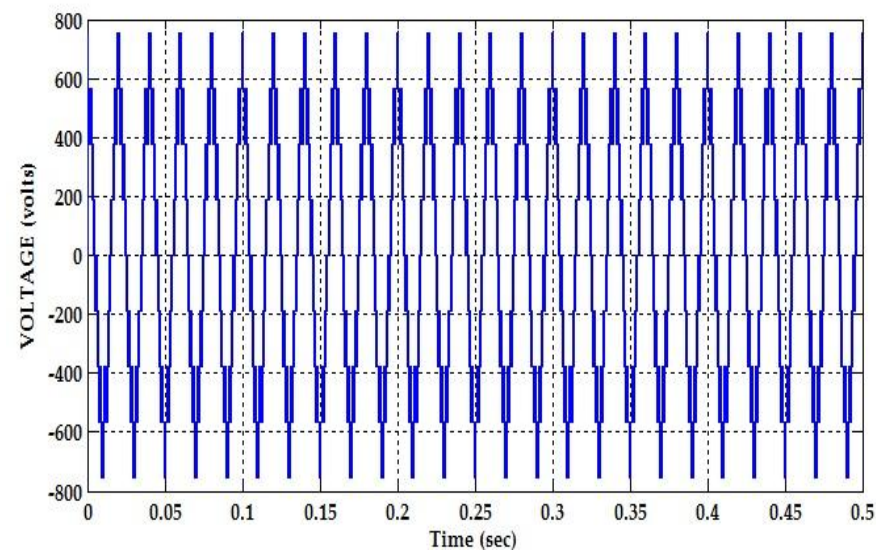

(a)

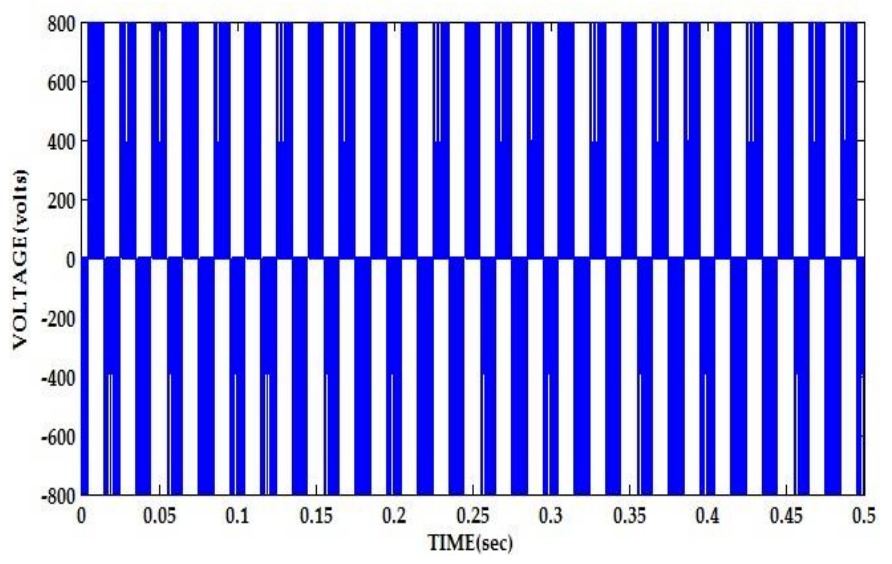

(b)

Fig-15 Line voltage $\mathrm{V}_{\mathrm{bc}}$ of induction motor load for (a) multilevel inverter (b)conventional inverter. 


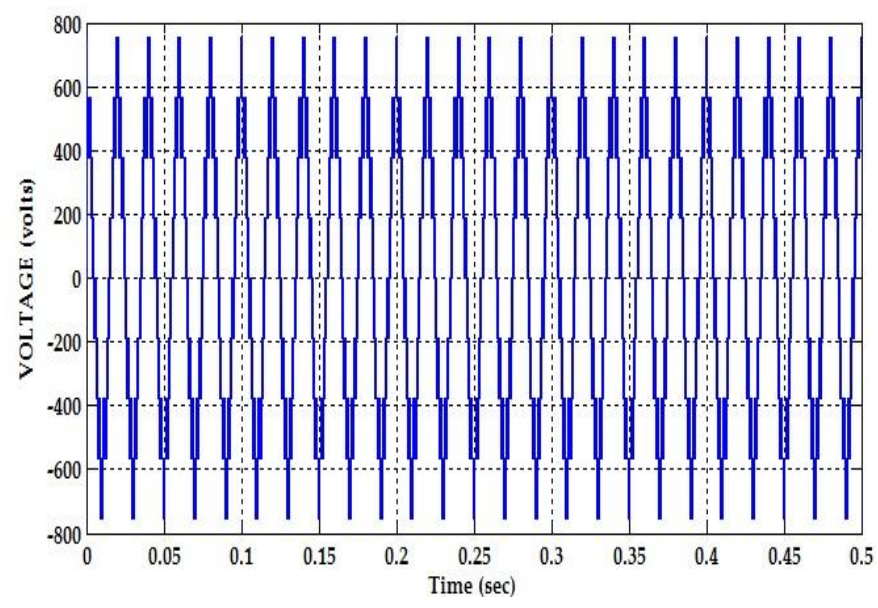

(a)

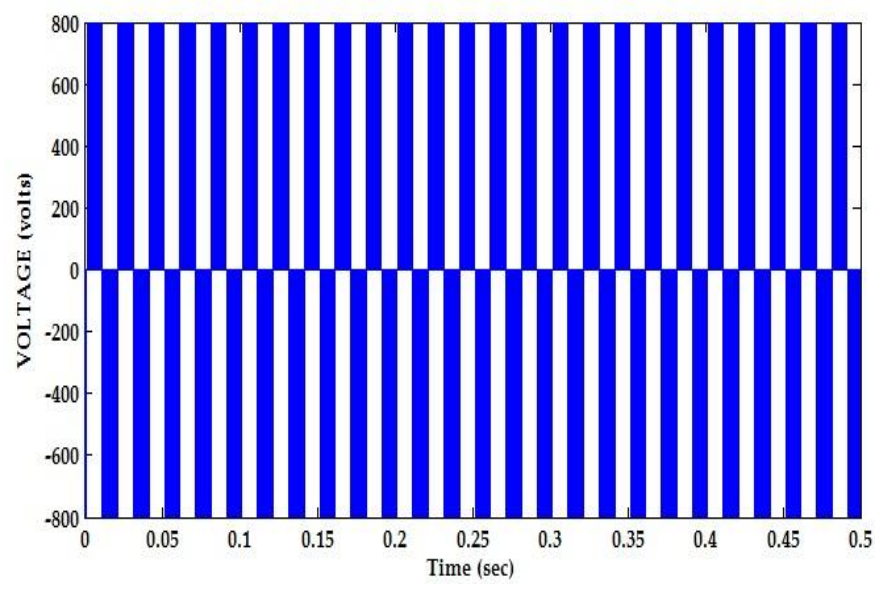

(b)

Fig-16 Line voltage $\mathrm{V}_{\mathrm{ac}}$ of induction motor load for (a) multilevel inverter (b) conventional inverter.

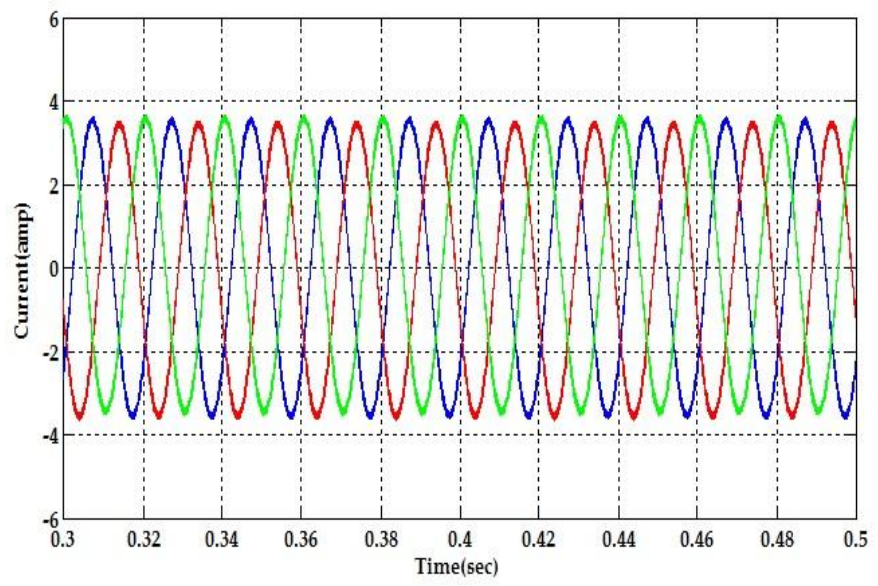

(a)

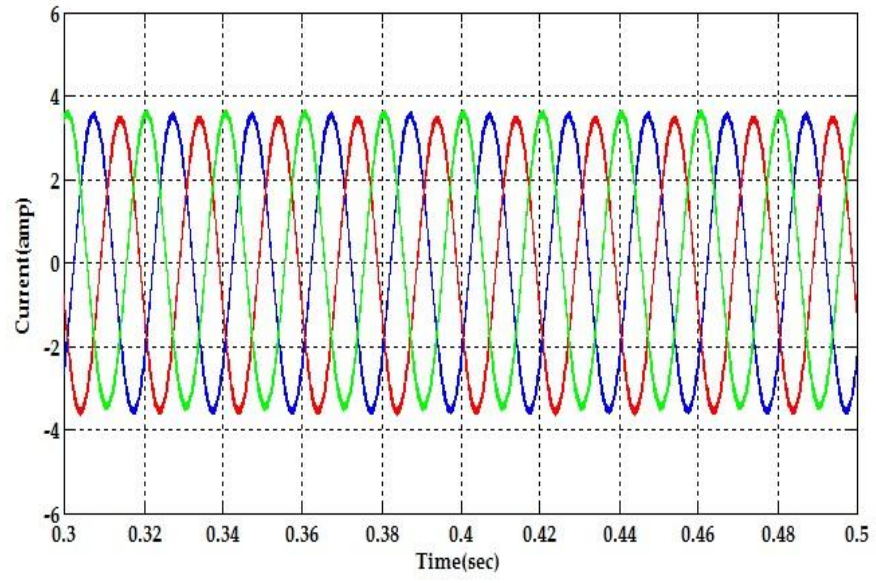

(b)

Fig-17 Three phase current of induction motor load for (a) multi-level inverter (b)conventional inverter.

\section{CONCLUSIONS}

A Five level cascaded multilevel Inverter is designed for induction motor drive. The simple popular PD pulse width modulation technique with switching frequency of $5 \mathrm{KHz}$ is considered for investigation. The performance of designed MLI fed induction motor drive is investigated for various modulation indices/frequencies under $0 \%, 50 \%$ and $100 \%$ load torque. The MLI fed induction motor drive is shown to perform well for various operating conditions. The performance of designed MLI is also compared with conventional two level three phase inverter in terms of THD. From the results obtained, it is observed that the MLI with five level has lesser THD in voltage and current. Thus the designed MLI is found to be a promising alternative for induction motor drives.

\section{REFERENCES}

[1]. L. Jih-Sheng and P. Fang Zheng, "Multilevel converters-a new breed of power converters," Industry Applications, IEEE Transactions on, vol. 32, pp. 509-517, 1996.

[2]. M. F. Escalante, J. C. Vannier, and A. Arzande, "Flying capacitor multilevel inverters and DTC motor drive applications," IEEE Trans. Ind. Electron., vol. 49, no. 4, pp. 809-815, Aug. 2002.

[3]. T. Ishida, K. Matsuse, T. Miyamoto, K. Sasagawa, and L. Huang, "Fundamental characteristics of five-level double converters with adjustable DC voltages for induction motor drives," IEEE Trans. Ind. Electron., vol. 49, no. 4, pp. 775782, Aug. 2002.

[4]. Teodorescu, R., Blaabjerg, F., Pedersen, J.K., Cengelci, E., Enjeti, P.N.: 'Multilevel inverter by cascading industrial VSI', IEEE Trans. Ind. Electron., 2002, 49, pp. 832-838

[5]. J. Dixon and L. Moran, "Multilevel inverter, based on multi-stage connection of three-level converters scaled in 
power of three," in IECON 02 [Industrial Electronics Society, IEEE 2002 28th Annual Conference of the], 2002, pp. 886-891 vol.2.

[6]. Lai, J.S., Peng, F.Z.: 'Multilevel converters - a new breed of converters', IEEE Trans. Ind. Appl., 1996, 32, pp. 509-517. [7]. M. D. Manjrekar, P. K. Steimer, and T. A. Lipo, "Hybrid multilevel power conversion system: a competitive solution for high-power applications," Industry Applications, IEEE Transactions on, vol. 36, pp. 834-841, 2000.

[8]. X. Yuan and I. Barbi, "Fundamentals of a new diode clamping multilevel inverter," IEEE Trans. Power Electron., vol. 15, no. 4, pp. 711-718, Jul. 2000.

[9]. Corzine, K.A., Familiant, Y.L.: 'A new cascaded multilevel H-bridge drive', IEEE Trans. Power Electron., 2002, 17, pp. $125-131$

[10]. J. Rodriguez, J. S. Lai, and F. Z. Zeng, "Multilevel inverters: A survey of topologies, controls and applications," IEEE Trans. Ind. Electron., vol. 49, no. 4, pp. 724-738, Aug. 2002.

[11]. J. Liao and M. Ferdowsi, "An improved cascaded Hbridge multilevel inverter controlled by an unbalanced voltage level sigma-delta modulator," in Proc. IEEE VPPC, Harbin, China, Sep. 2008, pp. 1-5.

[12]. P. Palanivel, S.S. Dash "Analysis of THD and output voltage performance for cascaded multilevelinverter using carrier pulse width modulation technique" IET Power Electronics vol. 4, no. 8, pp. 951-958, 2010.

[13]. Palanivel, P., Dash, S.S.: 'A FPGA based variable switching frequency multicarrier pulse width modulation for three phase cascaded multilevel inverter'. Proc. Int. Conf. on INCACEC-2009, Erode, India, June 2009, pp. 811-815

[14]. McGrath, B.P., Holmes, D.G., Meynard, T.: 'Reduced PWM harmonic distortion for multilevel inverter operating over a wide modulation range', IEEE Trans. Power Electron., 2006, 21, pp. 941-949.

[15]. Sirisukpraserl, S., Lai, J.S., Liu, T.H.: 'Optimum harmonic reduction with a wide range of modulation indices for multilevel converters', IEEE Trans. Ind. Electron., 2002, 49, pp. 875-881.

\section{APPENDIX}

The parameters of the induction machine used for simulation are given in the table shown below.

\section{Induction Motor Parameters}

\begin{tabular}{|l|l|ll|l|}
\hline Parameters & Values & \multicolumn{2}{|l|}{ Parameters } & Values \\
\hline Rated & $1.1 \mathrm{~kW}$ & Stator & Resistance & $6.03 \Omega$ \\
Power & $415 \mathrm{~V}$ & $\left(\mathrm{R}_{\mathrm{s}}\right)$ & & $6.085 \Omega$ \\
Rated & $2.77 \mathrm{~A}$ & Rotor & Resistance & $0.4893 \mathrm{H}$ \\
voltage & $3 \mathrm{Ph}$ & $\left(\mathrm{R}_{\mathrm{r}}\right)$ & $0.5192 \mathrm{H}$ \\
Rated & $50 \mathrm{~Hz}$ & Magnetizing & $0.5192 \mathrm{H}$ \\
current & 4 & Inductance $\left(\mathrm{L}_{\mathrm{m}}\right)$ & $0.011787 \mathrm{Kgm}^{2}$ \\
Type & $1415 \mathrm{RPM}$ & Stator $\quad$ Inductance & $0.0027 \mathrm{Kgm}^{2} / \mathrm{s}$ \\
\hline
\end{tabular}

\begin{tabular}{|c|c|}
\hline $\begin{array}{l}\text { Frequency } \\
\text { Number of } \\
\text { poles } \\
\text { Rated } \\
\text { Speed }\end{array}$ & $\mid \begin{array}{ll}\left(\mathrm{L}_{\mathrm{s}}\right) & \\
\text { Rotor } & \text { Inductance } \\
\left(\mathrm{L}_{\mathrm{r}}\right) & \\
\text { Total Inertia }\left(\mathrm{J}_{\mathrm{T}}\right) \\
\text { Friction } & \text { Coefficient } \\
(\mathrm{B}) & \end{array}$ \\
\hline
\end{tabular}

\section{BIOGRAPHIES}

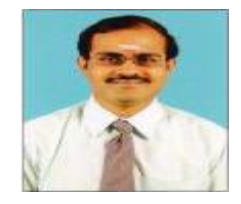

A.Venkadesan received his B.Tech degree in Electrical and Electronics Engineering (2007) and M.Tech degree in Electrical Drives \& control (2009) from Pondicherry Engineering College under Pondicherry University, Puducherry, India . He is currently pursuing his Ph.D degree in the area of AI Techniques applied to Electrical Drives in the same university. $\mathrm{He}$ is now working as an assistant professor in the department of EEE at SRM University. His areas of interest are Neural Network and Fuzzy applications to Electrical Drives \& control and Power Systems.

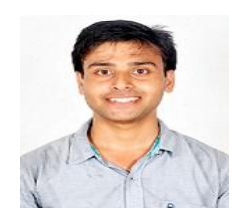

Priyatosh Panda Pursuing B.TECH degree in Electrical and Electronics Engineering from SRM University, Kattankulathur, Chennai,T.N, India. Areas of interest are power electronics, solid states and control.

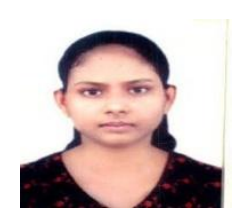

Priti Agrawal Pursuing B.TECH degree in Electrical and Electronics Engineering from SRM University, Kattankulathur, Chennai,T.N, India. Areas of interest are power electronics, electrical machines.

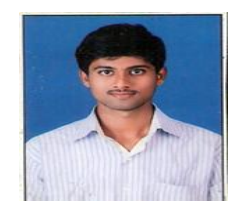

Varun. Puli Pursuing M.TECH degree in Electrical and Electronics Engineering from SRM University, Kattankulathur, Chennai,T.N, India. Areas of interest are estimators and controlling techniques. 